\title{
Why the CRISPR patent verdict isn't the end of the story
}

From legal challenges to ongoing experimentation, the story of who owns the rights to CRISPR-Cas9 gene editing is still being written.

Heidi Ledford

17 February 2017

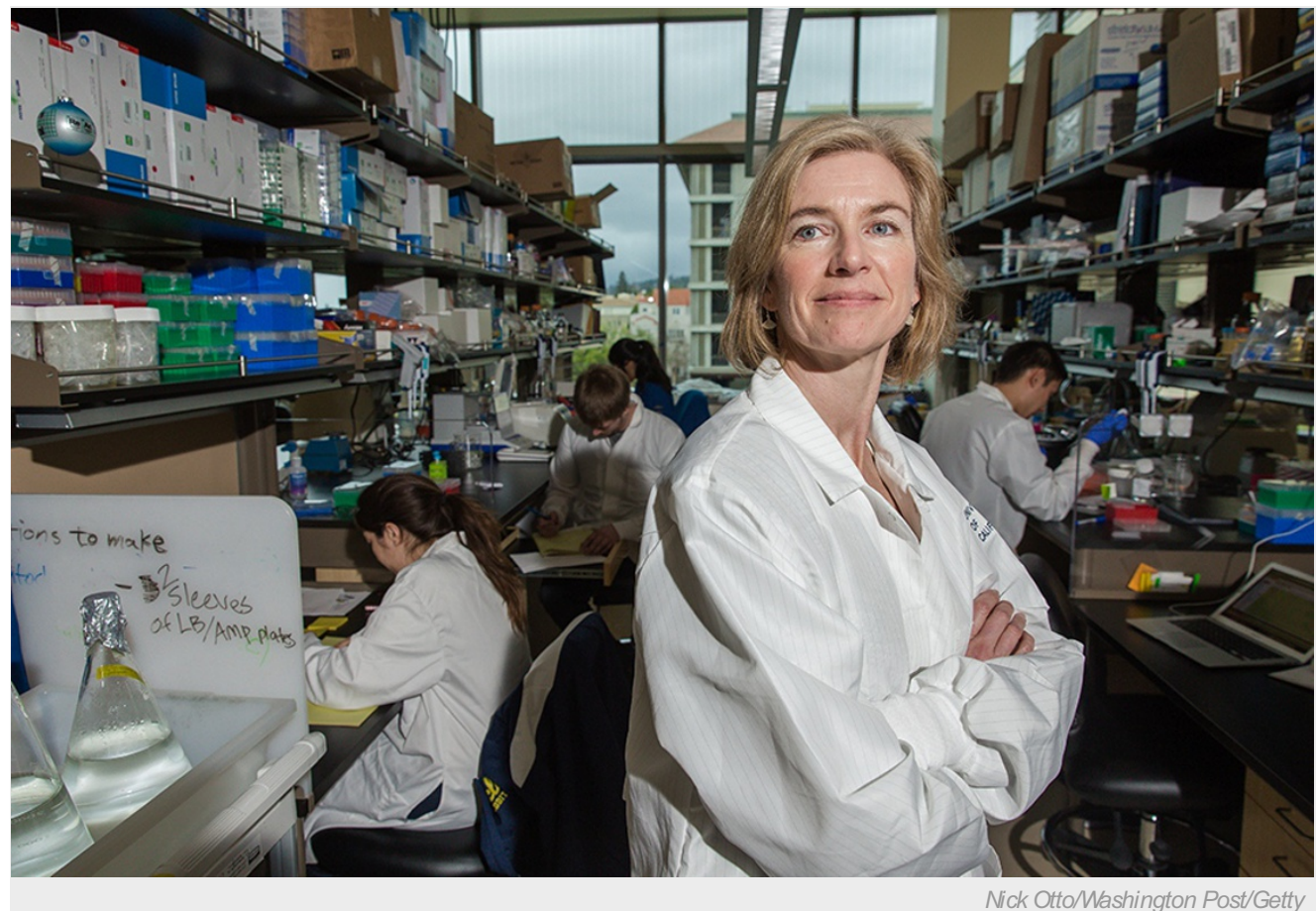

Molecular biologist Jennifer Doudna's camp at the University of California, Berekley, has lost a key battle over the rights to gene-editing technology CRISPR-Cas9.

The US Patent and Trademark Office (USPTO) issued a key verdict this week in the battle over the intellectual property rights to the potentially lucrative gene-editing technique CRISPR-Cas9.

It ruled that the Broad Institute of Harvard and MIT in Cambridge could keep its patents on using CRISPR-Cas9 in eukaryotic cells. That was a blow to the University of California, Berkeley, which had filed its own patents and had hoped to have the Broad's thrown out.

The fight goes back to 2012, when Jennifer Doudna at Berkeley, Emmanuelle Charpentier, then at the University of Vienna, and their colleagues outlined how CRISPR-Cas9 could be used to precisely cut isolated DNA ${ }^{1}$. In 2013, Feng Zhang at the Broad and his colleagues - and other teams - showed ${ }^{2}$ how it could be adapted to edit DNA in eukaryotic cells such as plants, livestock and humans.

Berkeley filed for a patent earlier, but the USPTO granted the Broad's patents first — and this week upheld them. There are high stakes involved in the ruling. The holder of key patents could make millions of dollars from CRISPR-Cas9's applications in industry: already, the technique has speeded up genetic research, and scientists are using it to develop disease-resistant livestock and treatments for human diseases.

But the fight for patent rights to CRISPR technology is by no means over. Here are four reasons why.

\section{Berkeley can appeal the ruling}

Berkeley has two months to appeal the USPTO's ruling — and may well do so. A key question is how confident Berkeley feels that its own patents, once granted, would cover the most lucrative applications of gene editing in eukaryotic cells, such as generating new crops or human therapies. 
The Broad's victory centred on a key difference: that its patents specified how CRISPR could be adapted for use in eukaryotic cells and Berkeley's didn't. This is why the USPTO ruled that the Broad's patents would not interfere with the granting of Berkeley's, and so should be allowed to stand.

Berkeley's team was quick to argue, in the wake of the decision, that its patent - if granted in its current state — would cover the use of CRISPR-Cas9 in any cell. That, the team says, would mean someone wanting to sell a product made using CRISPR-Cas9 in eukaryotic cells would need to license patents from both Berkeley and the Broad.

Yet the details of the USPTO's ruling could weaken Berkeley's chances of enforcing its patents in eukaryotic cells, patent scholars say. For example, much of the USPTO's 50-page decision argues that the use of CRISPR-Cas9 in eukaryotic cells - described in the Broad patent — required additional invention beyond that described in the Berkeley patent application.

So Berkeley may feel that it must still appeal. And its intellectual property is already licensed to several companies who intend to deploy CRISPR-Cas9 in eukaryotic cells. Those companies will probably prefer not to have to pay for a license from the Broad as well.

\section{European patents are still up for grabs}

Both teams have filed similar patents in Europe and are still battling for patent rights there.

And the decision in Europe may not necessarily follow the same path as the USPTO, notes Catherine Coombes, a patent lawyer at the intellectual-property specialists HGF in York, UK.

On the basis of European case law, the European Patent Office could choose to assess whether the discovery of the general geneediting system described in the Berkeley patent prompted "sufficient motivation" to try to make the leap to eukaryotic cells. If European judges find this to be the case, they could rule that the Berkeley patent covers eukaryotic applications of CRISPR-Cas9.

That could give Berkeley an edge that it lacked in the United States. "The fact that six groups got CRISPR-Cas9 to work in a eukaryotic environment within weeks of one another shows that in the field there was clear motivation to try," says Coombes.

Even so, there is likely to be no quick resolution to the European patent battle either: Coombes estimates that it could drag out for another five years or more.

\section{Other parties are also claiming patent rights on CRISPR-Cas9}

Attention has focused on the Berkeley-Broad battle because their patents are fairly broad and are seen as being crucial to most commercial applications of CRISPR-Cas9. But there are 763 patent families (groups of related patents) that claim Cas9, according to the consulting firm IPStudies near Lausanne, Switzerland. Of those, some claim patent rights to certain aspects of CRISPR-Cas9 gene editing. Over time, holders of those patents may try to assert those rights.

That may not happen until companies that use CRISPR-Cas9 start to make money from their products. At that point, someone who owns a related patent may sue for infringement and ask for royalties.

When the time comes, look for plenty of patent holders to come calling, says Jacob Sherkow, an intellectual property scholar at New York Law School in New York City. "Everybody and their third cousin twice removed is going to be claiming they have some inventorship interest in the Broad's patent," he says. "The Broad is going to be fighting those battles for years."

\section{CRISPR technology is moving beyond what the patents cover}

Researchers in academia and industry have been pushing CRISPR gene editing beyond the scope of the Broad and Berkeley patents.

Both patent families cover the use of CRISPR-Cas9, which relies on the Cas9 enzyme to cut DNA. But there are alternatives to Cas9 that provide other functions, and a way to sidestep the Berkeley-Broad patent fight.

One attractive alternative is Cpf1, an enzyme that may be simpler to use and more accurate than Cas 9 in some cases. The Broad has already filed patents on applications of Cpf1 in gene editing, and has licensed them to biotech company Editas Medicine in Cambridge, Massachusetts (which also has licenses for some Broad patents on CRISPR-Cas9). In all, there are already 28 patent families that claim Cpf1, according to IPStudies, and not all of them are from the Broad. 
Reports of other enzymes are trickling in. In December, researchers at Berkeley said that they had found two new Cas9 alternatives, Cas X and Cas $Y^{3}$. And some researchers may already be trying to patent unpublished alternatives — US patent applications typically do not become public until 18 months after they are filed.

Sherkow likens the situation to the early days of PCR (the polymerase chain reaction), a technique used to amplify segments of DNA that quickly became a vital tool in molecular biology. Laboratories initially used just one enzyme, Taq1 polymerase, to carry out the protocol. "Now if you go through the catalogue, there's almost an Amazon warehouse of polymerases that you can use depending on the particular reaction that you want to do," he says.

People are tethering the commercialization aspect of CRISPR to this particular patent fight, Sherkow says. "That's missing some of the broader picture."

Nature | doi:10.1038/nature.2017.21510

\section{References}

1. Jinek, M. et al. Science 337, 816-821 (2012).

2. Cong, L. et al. Science 339, 819-823 (2013).

3. Burstein, D. et al. Nature 452, 237-241 (2017).

\section{Evan Oto/SPL}

A molecular model of a Cas protein, which uses an RNA guide to cut DNA. 